\title{
EVALUATION OF BURNED AREAS WITH SENTINEL-2 USING SNAP: THE CASE OF KINETA AND MATI, GREECE, JULY $2018^{1}$
}

\author{
Kamill Daniel KOVÁCS ${ }^{2}$
}

DOI: $10.21163 / G T \_2019.142 .03$

\begin{abstract}
:
The aim of this paper is to compare the two largest forest fires that occurred in Greece in July 2018 using metrics for burned area and burn severity mapping, derived only from free satellite data. Sentinel-2 satellite images of the European Space Agency (ESA) within the Copernicus program provide a spatial resolution of $10 \mathrm{~m}$, which facilitates more accurate monitoring of environmental phenomena such as forest fires. The processing of the satellite images and the calculation of the metrics was performed using SNAP software, which is an open-source software developed by ESA. The mapping of the obtained results was performed in the QGIS software, which is also an open-source software. The delimitation of the burned area and the classification of the severity of both wildfires was performed using the Relativized Burn Ratio (RBR) satellite index. These results were contrasted with the Copernicus Emergency Management Service (EMS) maps related to these two events. Our results obtained in relation to the size of the burned area show smaller affected areas than the Copernicus Emergency Management Service maps. This is explained by the different methods used in the delimitation of the burned areas. In the case of Mati's wildfire the EMS has created the thematic layer by means of visual interpretation using post-event satellite image and in the case of Kineta's wildfire was applied a semi-automatic approach. Moreover, in this study is proposed and evaluated a new burn severity metric, the burned vegetation index (BVI) which shows where the most significant changes in healthy vegetation occurred. This new index was compared with RBR, dNDVI and dNBR using statistical correlation. The results indicate that BVI shows better the burned vegetation and its statistical correlation with RBR is significant $\left(R^{2}=0.92\right)$.
\end{abstract}

Key words: burned area mapping, burn severity, $R B R, B V I$.

\section{INTRODUCTION}

Fires are a common phenomenon in Mediterranean forest ecosystems, with regime change in the Mediterranean Basin mainly due to changes in land use and climate change (Pausas, 1999). According to Spanish statistics (MAPAMA, 2016) recorded from 1970 to 2010, the total number of forest fires in Spain showed a trend of decline. However, in the Euro-Mediterranean area, in recent decades, there has been a growing trend in the percentage of burned areas by large forest fires ( $>500$ ha) compared to the total burned area per year (San-Miguel-Ayanz \& Camia, 2009; Spano et al., 2014).

Following Keeley (2009), the concept of fire severity refers to the loss of organic matter both "on" and "under-soil" caused by the passage of fire, and should be differentiated from burn severity, which by including the response of the ecosystem (González-De Vega et al., 2015; Regueira et al., 2015; Fontúrbel et al., 2015) is more

\footnotetext{
${ }^{1}$ This work was presented at the "George Vâlsan" National Conference for Students held at the Babeș-Bolyai University, Faculty of Geography, 5-7 April 2019, Cluj-Napoca.

${ }^{2}$ Babeș-Bolyai University, 400006 Cluj-Napoca, Romania, kovcsdniel962@gmail.com
} 
complex to assess and involves prior knowledge of the existing community before the fire and its response to fire (Moya et al., 2009). In general, to estimate fire severity from satellite images, standardized methods based on spectral indices are used, such as the normalized difference vegetation index (NDVI) and the normalized burn ratio (NBR) (Chuvieco, 1999). The effect of fire on the ecosystem is closely linked to the burn severity (Vallejo et al., 2012; González et al., 2016), being greater the damage produced in vulnerable areas with low site quality, such as arid and semi-arid areas of Mediterranean climate (Hedo et al., 2014). This damage linked to the high burn severity can even affect instant energy flows (Sánchez et al., 2009) and their resilience (Paula et al., 2009; Tessler et al., 2014). Ecosystem resilience, understood as engineering resilience, is the rate of natural recovery to pre-disruption balance (Cantarello et al., 2017) and it is necessary to understand how certain transient states move from the transition to final stages (Doblas-Miranda et al., 2017). Knowing this problem is necessary for the correct sustainable management of the landscape, especially in areas sensitive to desertification, where the damage of recurrent and severe forest fires could lead the ecosystem to irreversible stages, causing the loss of ecosystem services (Doblas-Miranda et al., 2015), such as carbon storage capacity (Moya et al., 2014). Therefore, correct post-fire management must be based on knowledge of the relationships between ecosystem resilience, fire severity and ecosystem recovery (DíazDelgado \& Pons, 1999).

Numerous severity indices have been developed, highlighting the standardized NBR difference (dNBR), the standardized difference of NDVI (dNDVI) and the relative version of dNBR (RdNBR); all of them used as independent variables used to deduce the field indices of severity at the pixel level. There is a wide range of studies that demonstrate their sensitivity to changes in severity classes (Chu \& Guo, 2014). Both NDVI and NBR are widely validated for severity assessment, although the best results seem to be obtained from NBR-based indices (Escuin et al., 2008) as it combines two infrared bands (NIR and SWIR) that respond better to fire detection (Vlassova et al., 2014). However, the results are discussed given the low reliability in the zoning of soil severity with these methods versus those of vegetation (Vega et al., 2013) and the influence of several factors that determine the calculation, such as the local conditions, characteristics and conditions of pre- and postfire vegetation and the time elapsed in the assessment of severity (Chu \& Guo, 2014).

Consistent with major burn severity mapping efforts (Eidenshink et al., 2007), burn severity can be defined as the degree of fire-induced change to vegetation and soils, as measured with satellite image metrics (Parks, Dillon \& Miller, 2014). The two most commonly used satellite image-based metrics of burn severity are the delta normalized burn ratio (dNBR) (Key \& Benson, 2006) and its relativized form (RdNBR) (Miller \& Thode, 2007), both of which depend on the calculation of normalized burn ratio (NBR). NBR is sensitive to the amount of chlorophyll content in plants, moisture, and char or ash in the soil (Parks, Dillon \& Miller, 2014). All equations for dNBR, RdNBR and RBR use NBR derived from pre- and post-fire satellite images to quantify spectral change. All this metrics are sensitive to changes commonly caused by fire (Zhu et al., 2006; Hudak et al., 2007; Miller et al., 2009). However, the dNBR is an absolute difference which can present problems in areas with low pre-fire vegetation cover, where the absolute change between pre-fire and post-fire NBR will be small. In such cases the relativized version of burn severity (RBR) is advantageous and provides more accurate results (Equation 5) (Parks, Dillon \& Miller, 2014). Researchers and practitioners commonly classify these continuous metrics into categorical maps representing unchanged, low, moderate and high burn severity. 


$$
\begin{gathered}
\mathrm{dNDVI}=\mathrm{NDVI}_{\text {prefire }}-\mathrm{NDVI}_{\text {postfire }} \\
\mathrm{NBR}=\left(\frac{\mathrm{NIR}-\mathrm{SWIR}}{\mathrm{NIR}+\mathrm{SWIR}}\right)=\left(\frac{\text { Band } 8-\text { Band } 12}{\text { Band } 8+\text { Band } 12}\right) \\
\mathrm{dNBR}=\mathrm{NBR}_{\text {prefire }}-\mathrm{NBR}_{\text {postfire }} \\
\mathrm{RdNBR}=\frac{\mathrm{dNBR}}{\left|\left(\mathrm{NBR}_{\text {prefire }}\right)\right|^{0.5}} \\
\mathrm{RBR}=\left(\frac{\mathrm{dNBR}}{\left(\mathrm{NBR}_{\text {prefire }}+1.001\right)}\right)=\left(\frac{\mathrm{NBR}_{\text {prefire }}-\mathrm{NBR}_{\text {postfire }}}{\left(\mathrm{NBR}_{\text {prefire }}+1.001\right)}\right)
\end{gathered}
$$

For all this, the demand and need of managers to provide cartographic information on the fire severity, as a basis for quantifying and assessing damage on the ecosystem and its recovery should incentivize the work of researchers to find the more accurate and reliable method of calculation. The objective of this work is (1) to delimit the area and classify the burn severity in the case of these two Greek fires using the RBR index, (2) to compare the results with the estimates of Copernicus Emergency Management Service; (3) and also to present a new severity index for the study of wildfires, the burned vegetation index (BVI) that is recommended for the study and calssification of burned vegetation.

\section{STUDY AREA AND DATA}

Two large fires broke out on the central-southern Greece mainland (Attica region) on 23 July 2018, causing significant casualties, village evacuations, damage to property, while burning thousands of hectares of forestry. Regional Greek authorities have declared a state of emergency in the eastern and western parts of greater Athens, and the EU Civil Protection Mechanism has been activated to request for aerial and ground firefighting assests (Copernicus Emergency Management Service, 2018). The two affected localities were Kineta and Mati near by the capital city of Athens (Fig. 1). Kineta is a beach town in West Attica, situated on the northern coast of the Saronic Gulf, south of the Geraneia mountains. Mati is a village located on the east coast of Attica region, lies east of the Penteli mountains, on the Marathonas Avenue north of Rafina and south of Nea Makri. The

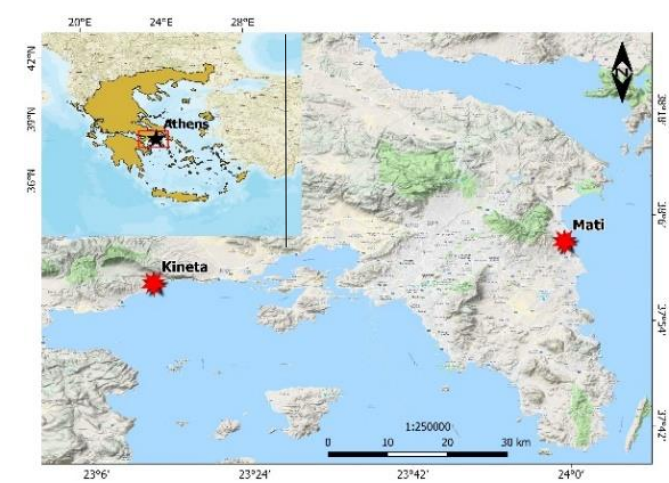

Fig. 1. Location of the two main fires, 23 July 2018. resident population of these localities was respectively 1,446 and 200 inhabitants in 2011 (Hellenic Statistical Authority, 2011).

The data used for this study are four Sentinel-2 products. Two data sets of pre-fire and post-fire satellite imagery were obtained for the study of the Kineta fire, and other two for the Mati fire. For the Kineta fire two Sentinel-2A Level 2A tiles (Tile ID: T34SFH) were acquired between on July 3, 2018 
(before the main event) and August 19, 2018 (after the main event). In the same way, for the Mati fire one Sentinel-2A Level 2A (Title ID: T34SFH) and another one Sentinel-2B Level 2B tiles (Tile ID: T34SGH) was acquired between on July 3, 2018 (before the main event) and August 4, 2018 (after the main event).

This four Sentinel-2 scenes have been downloaded free from the official Copernicus Open Access Hub website, operated by the European Space Agency (ESA) and the Copernicus Programme (Copernicus Open Access Hub, 2018). The first two scenes shown below are for Kineta pre-fire state and post-fire state, the last two for Mati pre-fire state and post-fire state.

S2A_MSIL2A_20180703T092031_N0208_R093_T34SFH_20180703T121025

S2A_MSIL2A_20180819T090551_N0208_R050_T34SFH_20180819T133811

S2A_MSIL2A_20180703T092031_N0208_R093_T34SFH_20180703T121025

S2B_MSIL2A_20180804T090549_N0208_R050_T34SGH_20180804T142040

Mathematical calculations and band combinations were processed with the following Sentinel-2 spectral bands: B3 (Green band), B8 (NIR band), B8A (Vegetation Red Edge), B11 and B12 (SWIR bands). In addition, two maps provided by Copernicus Emergency Management Service and two vector packages (available to open in a GIS interface) accompanied by these products have been obtained free (Fig. 2) (Copernicus EMS, 2018). With this data it was possible to compare our results related to the size of the burned areas.
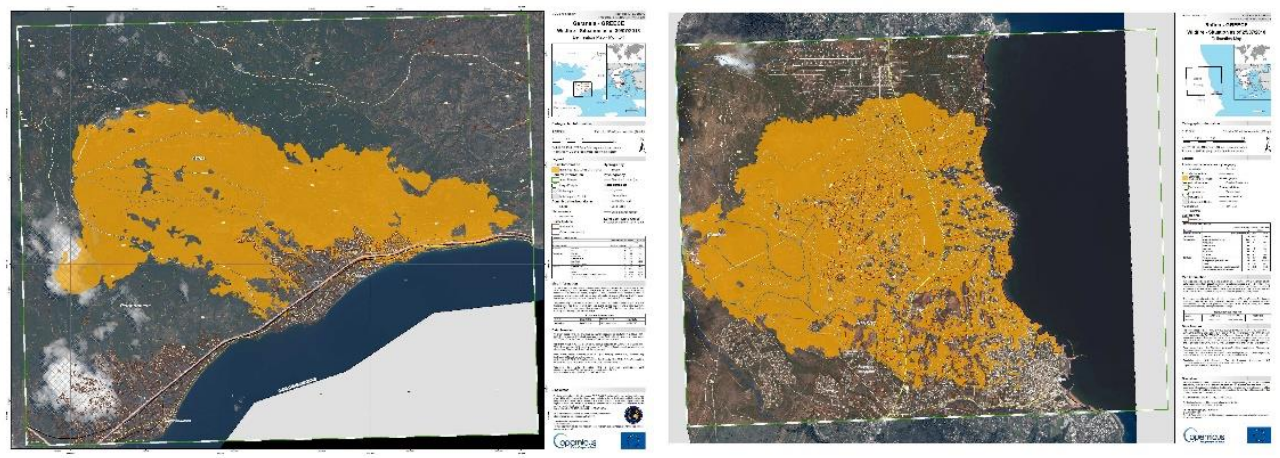

Fig. 2. Copernicus EMS maps of burned areas: Kineta (left), Mati (right) (Source: Copernicus EMS).

One of the major problems in Remote Sensing is the ability to have good data, which is, in particular, recorded at favourable time to highlight the objects or phenomena that are sought to be studied (Husson, 1983). In this case it was also essentially important that the areas of interest for this study are not covered by clouds in the satellite images. This is what primarily determines the selection of the time interval between satellite images.

\section{METHODOLOGY}

\subsection{Identification and extraction of burned areas}

Processing satellite data requires a GIS (Geographic Information System) environment. For data processing have been used the software SNAP (Sentinel-2 Toolbox), QGIS and Excel for subsequent statistical calculations.

For the Level $2 \mathrm{~A}$ products that have been used in this study the atmospheric correction has already been applied. Solar radiation reflected by the Earth's surface to satellite sensors is affected by its interaction with the atmosphere. The objective of applying an atmospheric 
correction is to determine true surface (Bottom-Of-Atmosphere, BOA) reflectance values from the Top-Of-Atmosphere (TOA) reflectance values, by removing atmospheric effects (Mousivand et al., 2015). Atmospheric correction is especially important in cases where multi-temporal images are compared and analysed as it is in this case (pre-fire and post-fire images). The SNAP software offers the integration of Sen2Cor algorithm for performing atmospheric correction. Sen2Cor is a processor for Sentinel-2 Level 2A product generation and formatting; it performs the atmospheric, terrain and cirrus correction of Top-OfAtmosphere Level 1C input data. Sen2Cor creates Bottom-Of-Atmosphere, optionally terrain and cirrus corrected reflectance images; additional, Aerosol Optical Thickness, Water Vapour, Scene Classification Maps and Quality Indicators for cloud and snow probabilities (Main-Knorn, 2017).

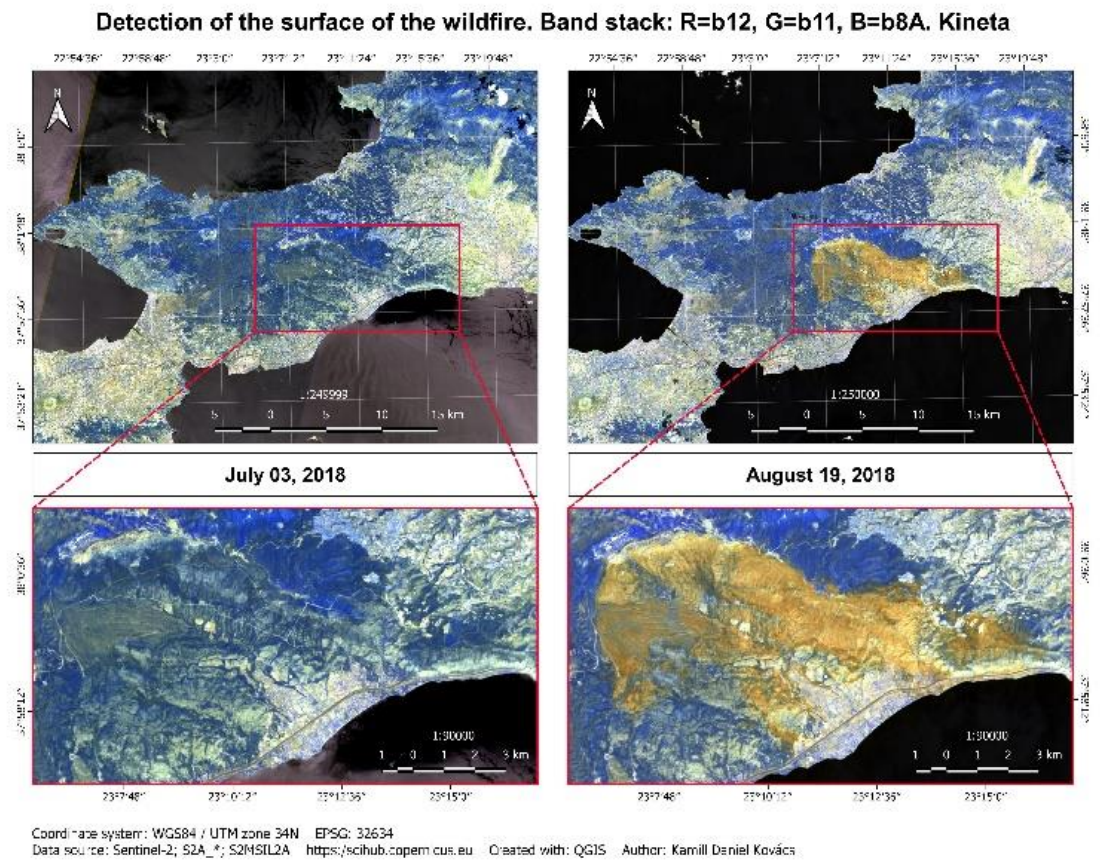

Fig. 3. Band stack, Kineta.

Atmospheric correction using Sen2Cor algorithm is a computationally heavy process and takes several time to be completed depending on the machine. However, since April 2017 the Level-2A products have already been generated and are available to download for acquisitions over Europe (such as this case).

To identify the newly burned areas, the following combination of bands has been established: Red: B12, Green: B11, Blue: B8A. It is possible to identify burned areas in true (natural) colours too but for distinguishing the burned areas it is better to use the Near InfraRed (NIR) and Short Wave InfraRed (SWIR) bands as these provide the best separability (Fig. 3). Likewise, newly burned areas can be well identified with the NDVI index (Equation 6) (Fig. 4, 5).

$$
\mathrm{NDVI}=\frac{\mathrm{NIR}-\mathrm{RED}}{\mathrm{NIR}+\mathrm{RED}}=\frac{\text { Band} 8-\mathrm{Band} 4}{\text { Band8-Band } 4}
$$


Detection of the surface of the wildfire. Normalized Difference Vegetation Index (NDVI).

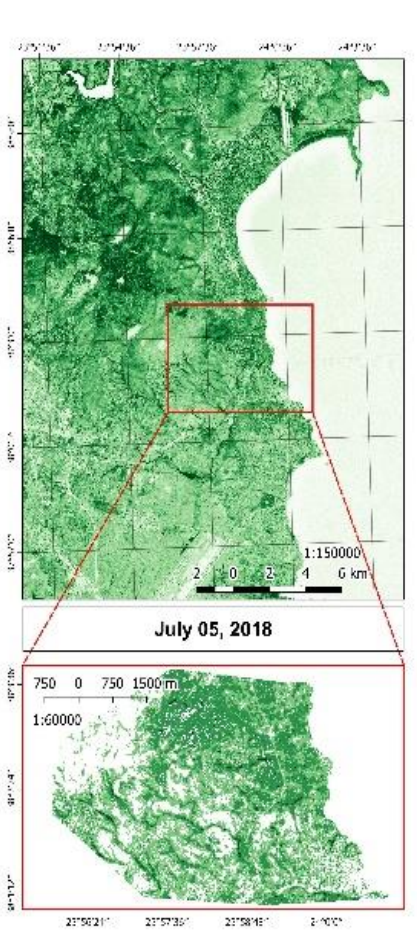
Mati, Greece

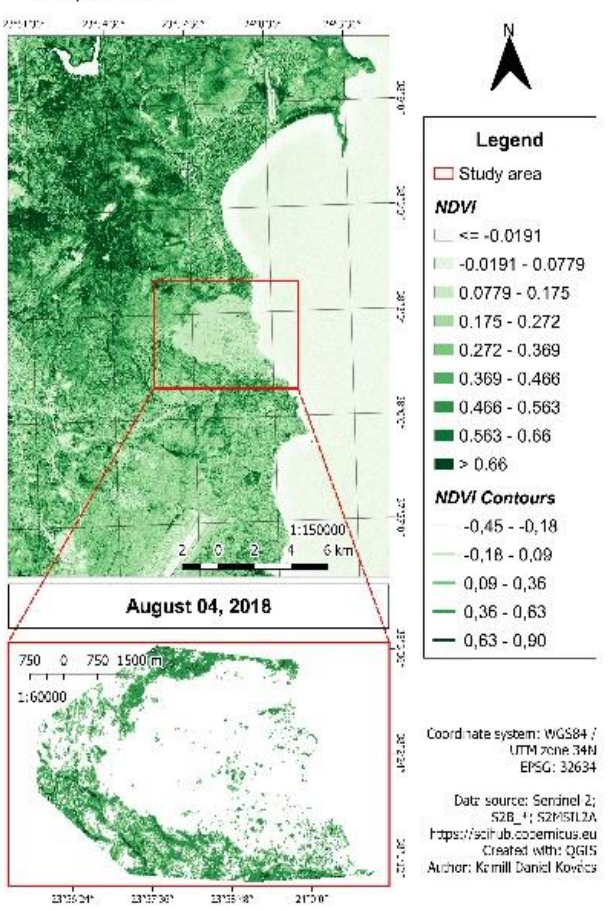

Fig. 4. Pre- and post-fire NDVI, Mati.

Detection of the surface of the wildfire. Normalized Difference Vegetation Index (NDVI). Kineta, Greece
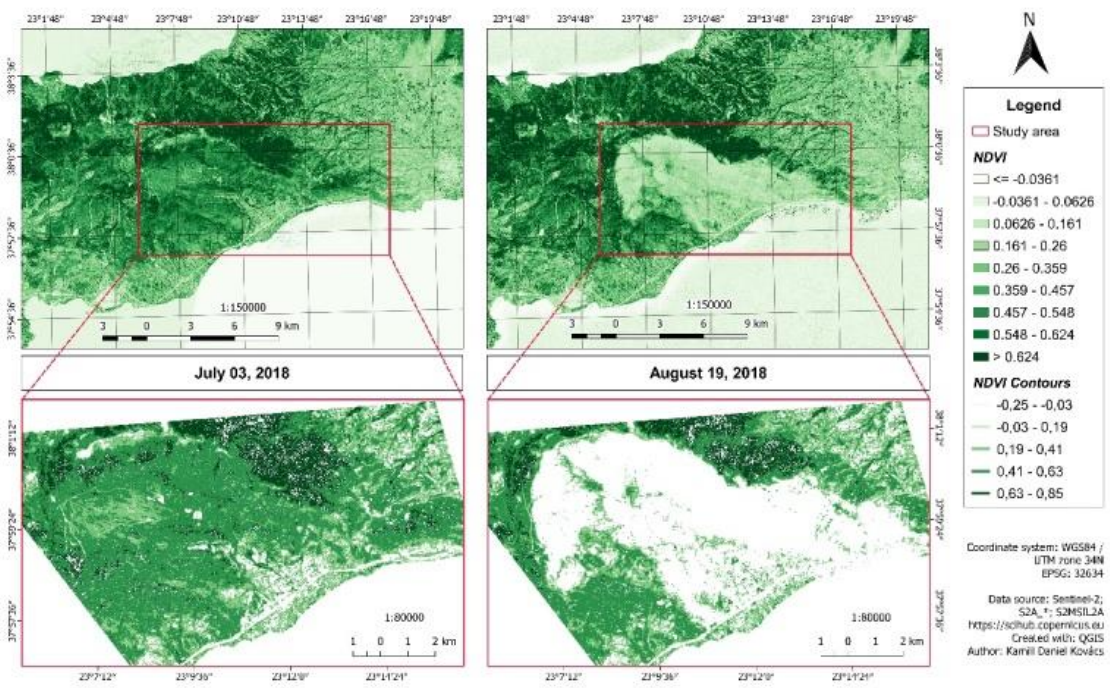

Fig. 5. Pre- and post-fire NDVI, Kineta. 
The Sentinel-2 L2-A product conveniently contains vector and cirrus cloud masks, which are created as a product of the atmospheric correction. However, applying the mask on all bands and the entire scene may take some time. A subset could have been done with the product, but the vector products are lost by that operation. So, in this case, to preserve the information a new band was created containing a cloud mask (Fig. 6). Currently, this is not possible to do using the Batch Processing tool in SNAP, so it has been necessary to add the cloud mask band to each product separately.

To identify pixels that contain clouds, the masks

scl_cloud_medium_proba,scl_cloud_high_proba, and scl_thin_cirrus

have been used with the following expression in Band Maths:

if (scl_cloud_medium_proba + scl_cloud_high_proba + scl_thin_cirrus) $<255$ then 0 else 1 .

The calculation results in a single mask band that contains all clouds.

As mentioned above, the Batch Processing tool available in SNAP allows the user to process all images at the same time, thus saving time with repetitive calculations. To use this tool, it was first necessary to define all the steps of the process that were to be executed. The process steps have been set with the GraphBuilder tool in SNAP. The advantage of the GraphBuilder tool is that no intermediate product will be physically saved, only the final product.

The input products contain 13 spectral bands in 3 different spatial resolutions $(10 \mathrm{~m}, 20$ $\mathrm{m}, 60 \mathrm{~m}$ ). The SWIR band (B12) that is a component of the NBR index calculation has a spatial resolution of $20 \mathrm{~m}$. Many operators do not support products with bands of different sizes so it was necessary to resample the bands to the equal resolution of $10 \mathrm{~m}$. The reference band for resampling was Band 2 (Blue) which has $10 \mathrm{~m}$ resolution (Fig. 6). The resampling method that was used is the bilinear interpolation method (Lyons et al., 2018). In the Subset tab the bands B3 (Green), B8 (NIR), B12 (SWIR) and the cloud mask band were selected. Only these bands are required for the following calculations of NBR and RBR.

The most commonly used metrics for burned area and burn severity mapping, derived from satellite data, is the normalized burn ratio (NBR) (Equation 2). Healthy vegetation has very high near-infrared reflectance and low reflectance in the shortwave infrared portion of the spectrum. Burned areas on the other hand have relatively low reflectance in the nearinfrared and high reflectance in the shortwave infrared band. A high NBR value generally indicates healthy vegetation while a low value indicates bare ground and recently burned areas.

After the calculation of NBR pre- and post-fire it was appropriate to merge all the preand post-fire bands and products into a single database (Collocation) (Fig. 6). With this merged database of the pre-processed products were calculated the changes in the pre- and post-fire NBR values.

Water bodies may show a similar NBR difference in certain circumstances, therefore they needed to be masked. It was also important to mask the clouds that occur in any of the input images. For this purpose, a single combined mask of water and clouds has been created. 


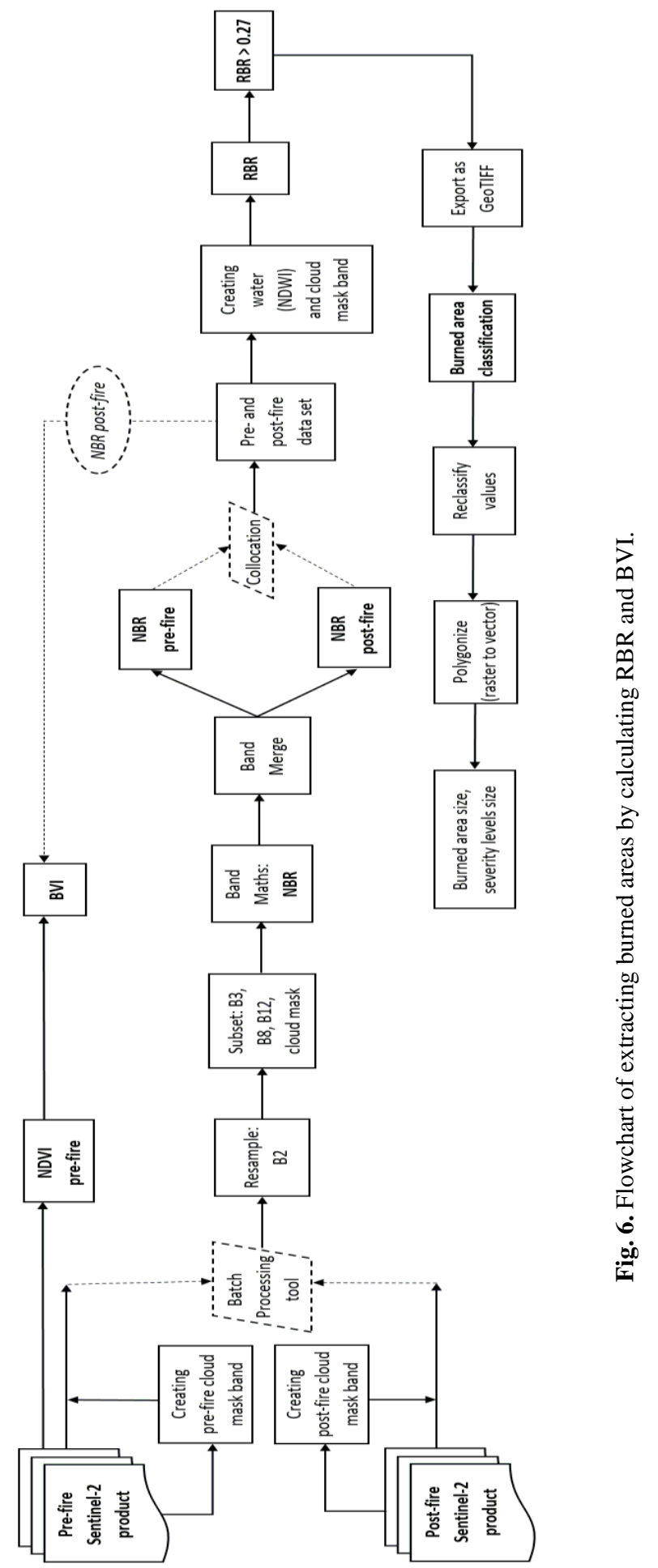


The Normalized Difference Water Index (NDWI) has been used to detect water bodies. The NDWI proposed by McFeeters is designed to maximize the reflectance of the water body in the green band and to minimize the reflectance of water body in the NIR band. McFeeters's NDWI is calculated as (Du et al., 2016):

$$
\text { NDWI }=\frac{\text { Green }- \text { NIR }}{\text { Green }+ \text { NIR }}=\frac{\text { B3 }- \text { B8 }}{B 3+B 8}
$$

The water and cloud mask was calculated with the following expression in Band Maths:

if (cloud_mask_pre-fire $>0$ or cloud_mask_post-fire $>0$ or ((B3_pre-fire - B8_pre-fire)/ $($ B3_pre-fire + B8_pre-fire) $)>=0.0$ ) then 1 else 0 .

To identify recently burned areas and differentiate them from bare soil and other nonvegetated areas we used the Relativized Burn Ratio (RBR) (Equation 5). The RBR is the dNBR divided by a simple adjustment to the pre-fire NBR. Adding 1.001 to the denominator ensures that the denominator will never be zero, thereby preventing the equation from reaching infinity and failing (Parks, Dillon \& Miller, 2014). With the calculation of the RBR it has also been applied the cloud and water mask. The RBR was calculated with the following expression in Band Maths: if cloud_water_mask $==0$ then ((NBR_pre-fire - NBR_post-fire)/(NBR_pre-fire + 1.001)) else NaN.

To extract only the burned area, another band has been created by establishing a threshold for pixel to be classified as burned to > 0.27 (Keeley, 2009; UN-SPYDER Knowledge Portal). Only those pixels where RBR is larger than 0.27 have been selected. This value of 0.27 corresponds to moderate burn severity areas. Therefore, only areas classified as moderate burn or higher have been selected. To extract this pixels the following expression was introduced in BandMaths: if RBR > 0.27 then RBR else NaN.

After exporting the burned area in GeoTIFF (*.tif, *.tiff) format, burn severity has been interpreted in QGIS according to the following table (Table 1). This values are proposed by The United States Geological Survey (USGS) to interpret the burn severity (dNBR).

Burn severity levels obtained calculating dNBR, proposed by USGS

Table 1. (Source: Keeley, 2009; UN-SPYDER Knowledge Portal)

\begin{tabular}{|l|c|c|c|}
\hline Severity Level & dNBR range (scaled by $\mathbf{1 0}^{\mathbf{3}}$ ) & & dNBR (not scaled) \\
\hline Enhanced Regrowth, hight & -500 to -251 & & -0.500 to -0.251 \\
\hline Enhanced Regrowth, low & -250 to -101 & & -0.250 to -0.101 \\
\hline Unburned & -100 to +99 & & -0.100 to 0.099 \\
\hline Low Severity & +100 to +269 & & 0.100 to 0.269 \\
\hline Moderate-low Severity & +270 to +439 & & 0.270 to 0.439 \\
\hline Moderate-high Severity & +440 to +659 & 0.440 to 0.659 \\
\hline High Severity & +660 to +1300 & & 0.660 to 1.300 \\
\hline
\end{tabular}

In order to calculate the size of the burned area, the obtained raster has been polygonized. The vectorization process was done in QGIS, with the Reclassify values (simple) (SAGA GIS) and Polygonize (raster to vector) (GDAL) tools. In the process of reclassifying the values, only the values belonging to categories Low Severity, Moderatelow Severity, Moderate-high Severity and High Severity have been reclassified, assigning to these categories the numbers $0,1,2,3$, respectively. After the reclassification, these burn severity categories have been polygonized. Obtaining the burned area in a vector format has allowed to calculate the size of the area affected by fire; and also by reclassifying the values 
has allowed to calculate the area of the different severity categories, thus obtaining greater detail of the fire. In the QGIS attribute table has calculated the size of the areas of the different severity categories in square meters and hectares. With the help of Excel, the size of the total affected area and the size of the different severity classes were calculated.

\subsection{Calculation of the Burned Vegetation Index (BVI)}

To present an alternative metric in the study of fire severity, the Burned Vegetation Index (BVI) has been developed which combines the Normalized Difference Vegetation Index (NDVI) and the Normalized Burn Ratio (RBR) for the study of the severity of burned vegetation. The BVI is defined as a difference between NDVI pre-fire and NBR post-fire:

$$
\begin{gathered}
\mathrm{BVI}=\left(\frac{\mathrm{NIR}_{\text {prefire }}-\mathrm{Red}_{\text {prefire }}}{\mathrm{NIR}_{\text {prefire }}+\mathrm{Red}_{\text {prefire }}}\right)-\left(\frac{\mathrm{NIR}_{\text {postfire }}-\mathrm{SWIR}_{\text {postfire }}}{\mathrm{NIR}_{\text {postfire }}+\mathrm{SWIR}_{\text {postfire }}}\right) \\
\mathrm{BVI}=\mathrm{NDVI}_{\text {prefire }}-\mathrm{NBR}_{\text {postfire }}
\end{gathered}
$$

The BVI first identifies the healthy vegetation reflected in the red and near-infrared bands, and then subtracts from this the pixels identified as burned areas reflected in nearinfrared and shortwave infrared bands. Vegetation in good condition has high near-infrared reflectance and low reflectance in the shortwave infrared portion of the spectrum. Otherwise, burned areas have low reflectance in the near-infrared and high reflectance in the shortwave infrared band. Therefore, the pre-fire NDVI gives larger values where vegetation was healthier, while the post-fire NBR gives negative values for surfaces identified as recently burned. As a result of the subtraction, the BVI shows smaller values where vegetation remains healthy and larger values where vegetation suffered fire disturbance. The following classification table is proposed to interpret the BVI (Table 2). The values were classified into five severity categories by equal intervals. The interval values shown in the table were obtained by calculating the mean of the category values in the case of the two fires.

Table 2.

Burned vegetation severity levels obtained calculating BVI (Source: the author).

\begin{tabular}{|l|c|}
\hline Severity Level & BVI \\
\hline Highly healthy vegetation & $<=0.124$ \\
\hline Healthy vegetation & 0.125 to 0.286 \\
\hline Bare soil & 0.287 to 0.449 \\
\hline Moderately burned vegetation & 0.450 to 0.612 \\
\hline Highly burned vegetation & $>=0.613$ \\
\hline
\end{tabular}

\subsection{Analysis of the relationship between BVI and RBR, dNDVI, dNBR}

For the statistical analysis of the relationship between satellite indices, first has been calculated the number of pixels that exist in each study area $(\mathrm{N}$, population size) with the Zonal Statistics tool in QGIS. Having the total number of pixels in the study area, the size of a sample was calculated with a confidence level of $95 \%$ and with a margin of error of $5 \%$, using the following formula (Israel, 1992):

$$
n=\frac{n_{0}}{1+\frac{\left(n_{0}-1\right)}{N}}
$$

where $\mathrm{n}$ is the sample size, $\mathrm{N}$ is the population size, and $\mathrm{n}_{0}$ is calculated as follows: 


$$
n_{0}=\frac{z^{2} p q}{e^{2}}
$$

where $\mathrm{n}_{0}$ is the sample size, $\mathrm{Z}^{2}$ is the abscissa of the normal curve that cuts off an area $\alpha$ at the tails $\left(1-\alpha\right.$ equals the desired confidence level, e.g., 95\%), $\mathrm{e}^{2}$ is the desired level of precision, $p$ is the estimated proportion of an attribute that is present in the population, and $\mathrm{q}$ is 1-p. The value for $\mathrm{Z}$ is found in statistical tables which contain the area under the normal curve. With the help of the Random points in layer bounds tool in QGIS, the required number of points of the calculated sample has been generated. In QGIS there is another tool that allows to extract the pixel value using a vector layer that contains the sampling points and the raster layers with field/bands to get values from. Thus, with the Point Sampling tool, the pixel values that were taken in the sample were extracted for correlation analysis between satellite indices. The intensity of linear relationship between satellite indices was determined using by Pearson correlation coefficient (r). The Pearson correlation coefficient (r) of two variables, xi and yi, was calculated on the basis of the following equation (Lee \& Wong, 2001):

$$
r=\frac{\frac{\sum_{i=1}^{n} x i y i}{n}-\bar{X} \bullet \bar{Y}}{S x S y}
$$

where, $\bar{X}$ and $\bar{Y}$ represent the mean of $\mathrm{x}$ and $\mathrm{y}$, and $S x$ and $S y$ represent standard deviation of $\mathrm{x}$ and $\mathrm{y}$, calculated with the formulas:

$$
S x=\sqrt{\frac{\sum_{n=1}^{n} x^{2}}{n}}-\bar{X}^{2} S y=\sqrt{\frac{\sum_{n=1}^{n} y^{2}}{n}}-\bar{Y}^{2}
$$

Pearson's correlation coefficient was validated with a t-test. The object of the t-test of a correlation coefficient is to investigate whether the difference between the sample correlation coefficient and zero is statistically significant. It is assumed that the $\mathrm{x}$ and $\mathrm{y}$ values originate from a bivariate normal distribution, and that the relationship is linear (Kanji, 2006). To test the null hypothesis that the population value of $r$ is zero, the follow test statistic has been calculated:

$$
t=\frac{r}{\sqrt{1-r^{2}}} * \sqrt{n-2}
$$

This t-test follows Student's t-distribution with $n-2$ degrees of freedom and in this case was two-tailed.

\section{RESULTS AND DISCUSSIONS}

The delimitation and extraction of the two areas affected by forest fires with the calculation of the RBR index gave different results compared to Copernicus EMS maps. The size of the burned area according to the calculation process of this study in the case of Kineta is 3511 hectares, presenting the following distribution of burn severity: Low Severity: 493 ha (14\%), Moderate-low Severity: 1483 ha (42\%), Moderate-high Severity: 1370 ha (39\%), High Severity: 164 ha (5\%) (Fig. 7). On the other hand, the size of the affected area in the case of Mati is 942 hectares, presenting the following distribution of burn severity: Low Severity: 76 ha (8\%), Moderate-low Severity: 369 ha (39\%), Moderatehigh Severity: 271 ha (29\%), High Severity: 226 (24\%) (Fig. 8). EMS data (emergency maps and vector packages) estimates the size of the burned area in Kineta at 5613 hectares and in Mati at 1275 hectares (Copernicus EMS, 2018). 
These differences in the size of the areas affected by the same fire are explained by the different methods used in the delimitation of the burned areas. In the case of Mati the EMS thematic layer has been derived from post-event satellite image, using by means of visual interpretation. The estimated geometric accuracy is $5 \mathrm{~m} \mathrm{CE} 90$ or better, from native positional accuracy of the background satellite image. Data sources they used are very high resolution Pléiades pre- and post-fire satellite images. The pre-event image is a Pléiades1A/B, distributed by Airbus DS, acquired on 07/03/2018, with a ground sampling distance (GSD) of $0.5 \mathrm{~m}$, approximately $0 \%$ cloud coverage. The post-event image is a Pléiades-1B acquired on 25/07/2018, with a ground sampling distance (GSD) of $0.5 \mathrm{~m}$, approximately $2.3 \%$ cloud coverage. In the case of Kineta the EMS thematic layer has been derived from post-event satellite image using a semi-automatic approach. The pre-event image in this case was a SPOT6/7, distributed by Airbus DS acquired on 06/12/2017, with a ground sampling distance (GSD) of $1.5 \mathrm{~m}$, approximately $0 \%$ cloud coverage. The post-event image was also a SPOT6/7, acquired on 30/07/2018, with a ground sampling distance (GSD) of 1.5 m, approximately 5.6\% cloud coverage (Copernicus EMS, 2018).

Both visual interpretation and semi-automatic classification of land cover are methods often used in Remote Sensing (Cigna et al, 2011; Cigna et al., 2012; Raspini et al., 2018; Jiang et al., 2012), but in the case of the study and mapping burned areas they give very different results. Firstly, because the methodology for the delimitation and interpretation of the results always depends on the researcher and the purpose of the study for which it is done; and secondly, because the study of the change of land cover in Remote Sensing depends a lot on the date and time when the satellite images were taken, the season of the year in which they were taken, the atmospheric conditions and the time interval between the images.

The Burned Vegetation Index (BVI) in the study and mapping burned areas is focused on represent fire-altered vegetation (Fig. 9, Fig. 10). It captures changes in vegetation using the Red, NIR and SWIR bands of the electromagnetic spectrum. The correlation analysis between BVI and different fire severity metrics (RBR, dNDVI, dNBR) has shown that the BVI corresponds very well with other satellite indices used in the study and mapping burned areas (Fig. 11). In the study area of Kineta there were 1169238 pixels, of which a sample of 384 points was taken with the values associated with its pixels. The study area of Mati contained 249468 pixels, of which a sample of 384 points was taken with the values associated with its pixels. In the case of the relationship between BVI and RBR, the Pearson correlation coefficient (r) gave the value $r=0.96$ (Kineta) and $r=0.94$ (Mati). The relationship between BVI and dNDVI was $r=0.93$ (Kineta) and $r=0.90$ (Mati). The relationship is also strong in the case of BVI and dNBR giving $r=0.96$ (Kineta) and $r=0.94$ (Mati). The coefficient of determination $\left(\mathrm{R}^{2}\right)$ using linear regression in the case of BVI and RBR is $\mathrm{R}^{2}=0.92$ (Kineta) and $\mathrm{R}^{2}=0.89$ (Mati). In the case of $\mathrm{BVI}$ and dNDVI the coefficient of determination is $\mathrm{R}^{2}=0.87$ (Kineta) and $\mathrm{R}^{2}=0.82$ (Mati). The coefficient of determination is also high between BVI and dNBR: $\mathrm{R}^{2}=0.92$ (Kineta) and $\mathrm{R}^{2}=0.88$ (Mati) (Table 3). The t-test of the correlation coefficient validated that the difference between the correlation coefficient and zero is statistically significant in all cases between BVI and RBR, dNDVI, dNBR. With this it can be affirmed that there is a statistically significant relationship between BVI and RBR, dNDVI, dNBR. The t-test was taken with a confidence level of $95 \%(C L)$, margin of error $5 \%(\alpha)$ and with the probability of $t \alpha / 2=0.975$. Establishing this, the critical value of the T-Student table according to the degree of freedom $(\mathrm{df}=\mathrm{n}-2)$ in all cases is $1.96(\mathrm{df}=381$ in the case of Kineta and $\mathrm{df}=364$ in the case of Mati). Between BVI and RBR, dNDVI, dNBR the T-test value (T-stat) is greater than 
the critical value (T-critical), stating that there is statistically significant relationship between the variables (Table 3).

In the study of forest fires, it is not sufficient to assess and delimit the affected areas after the event. From a socio-economic perspective it is important to develop vulnerability models to wildfires. Further studies underline the need to find optimal ways of evacuating the population in cases of forest fires (Hasnat et al., 2018; Nicoară \& Haidu, 2014). In addition, the study of burned areas with Remote sensing methods in other studies is complemented by meteorological indicators (Furtună \& Holobâcă, 2013). Mateescu (2006) in its study on post-fire assessment introduces the dedicated BAS2 tool for wildfires. From a hydrological perspective, Sever's study (2019) reveals the impact of mega-fires on watersheds.

Table 3.

The degree of dependence between BVI and RBR, dNDVI, dNBR.

\begin{tabular}{|l|c|c|c|c|c|}
\hline Relationship/Fire & $\mathbf{r}$ & $\mathbf{R}^{\mathbf{2}}$ & T-stat & T-critical & df \\
\hline BVI \& RBR (Kineta) & 0.96 & 0.92 & 67.8 & 1.96 & 381 \\
\hline BVI \& RBR (Mati) & 0.94 & 0.89 & 54.2 & 1.96 & 364 \\
\hline BVI \& dNDVI (Kineta) & 0.93 & 0.87 & 49.7 & 1.96 & 381 \\
\hline BVI \& dNDVI (Mati) & 0.90 & 0.82 & 40.2 & 1.96 & 364 \\
\hline BVI \& dNBR (Kineta) & 0.96 & 0.92 & 67.6 & 1.96 & 381 \\
\hline BVI \& dNBR (Mati) & 0.94 & 0.88 & 52.4 & 1.96 & 364 \\
\hline
\end{tabular}

\section{Classification of the wildfire's surface. Relativized Burn Ratio (RBR). Kineta}

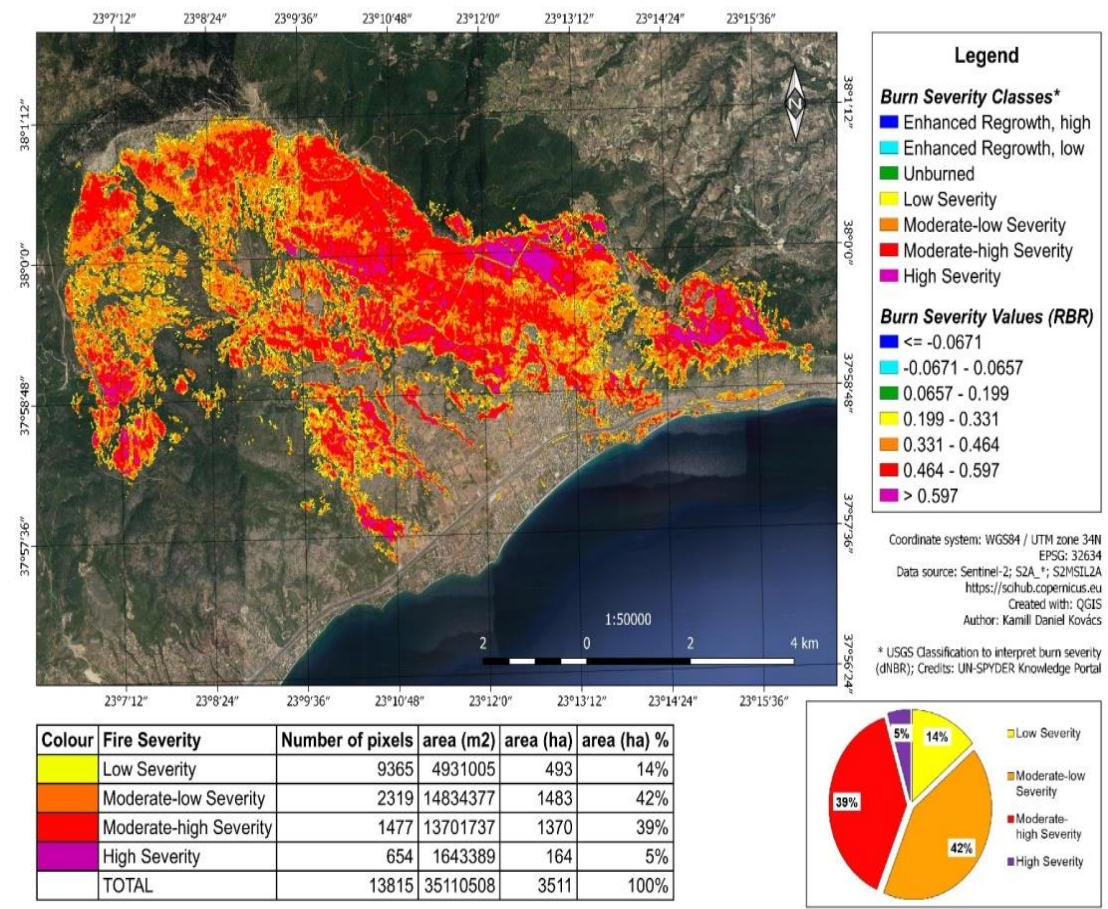

Fig. 7. Burned area size and burn severity levels, Kineta. 
Classification of the wildfire's surface. Relativized Burn Ratio (RBR). Mati

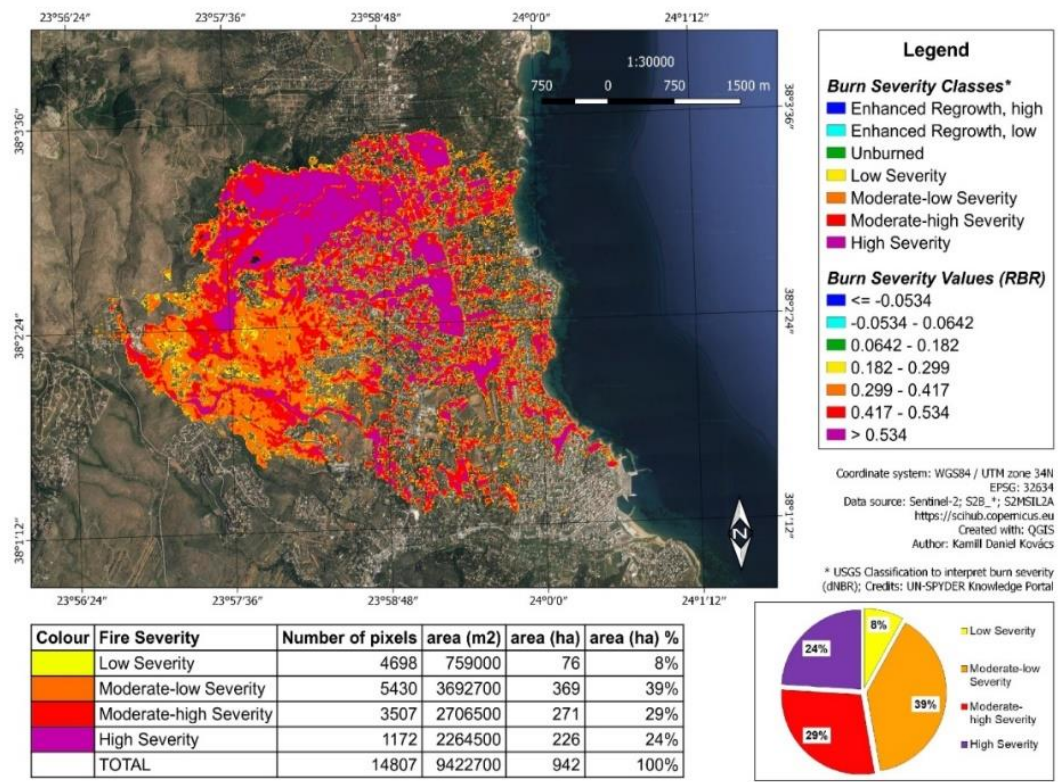

Fig. 8. Burned area size and burn severity levels, Mati.

\section{Classification of the wildfire's surface. Burned Vegetation Index (BVI). Kineta}

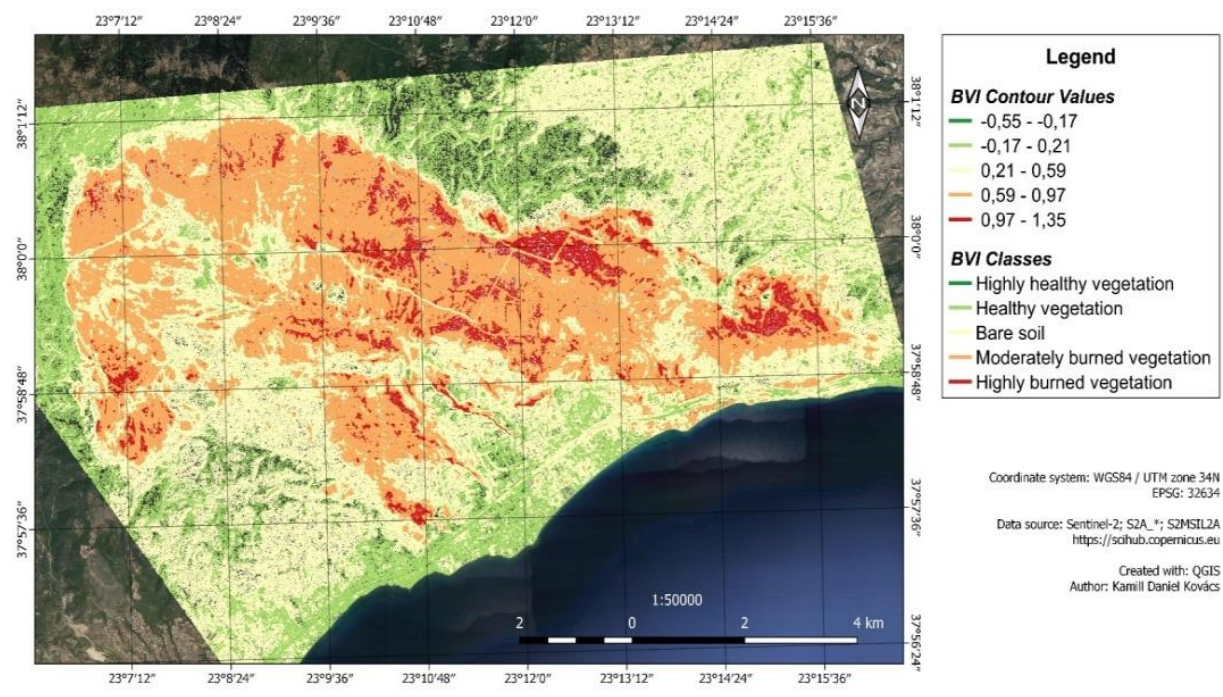

Fig. 9. BVI severity levels, Kineta. 


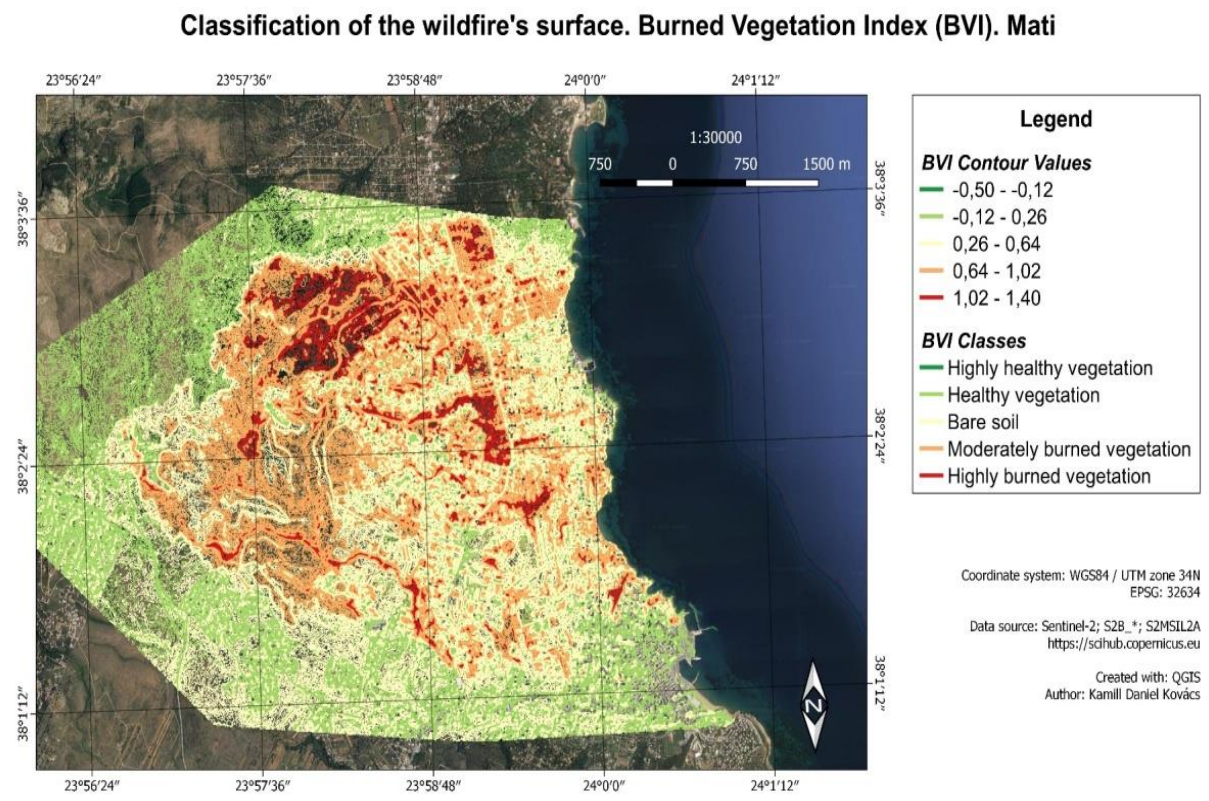

Fig. 10. BVI severity levels, Mati.

\section{CONCLUSIONS}

Sentinel-2 satellite images available for free are a good source of data for analyzing and interpreting burn severity of forest fires because they have a relatively high spatial resolution of $10 \mathrm{~m}$. However, Copernicus EMS data have shown that the delimitation of the area affected by fire is based on criteria defined by the researcher and also depends on the purposes of the investigation. In this study, the affected areas have been delimited with the calculation of the RBR index and according to the USGS proposition to interpret burn severity, setting a threshold of RBR $>0.27$ to extract only the areas that were burned. EMS maps are developed to handle emergencies, therefore reflect situations almost immediately after the events (a few days after the event). Moreover, the study of the relationship between BVI and RBR, dNDVI, dNBR demonstrated that BVI is a good alternative for the study of wildfires, specially adapted for fire-altered vegetation research. 
BVI \& RBR. Kineta
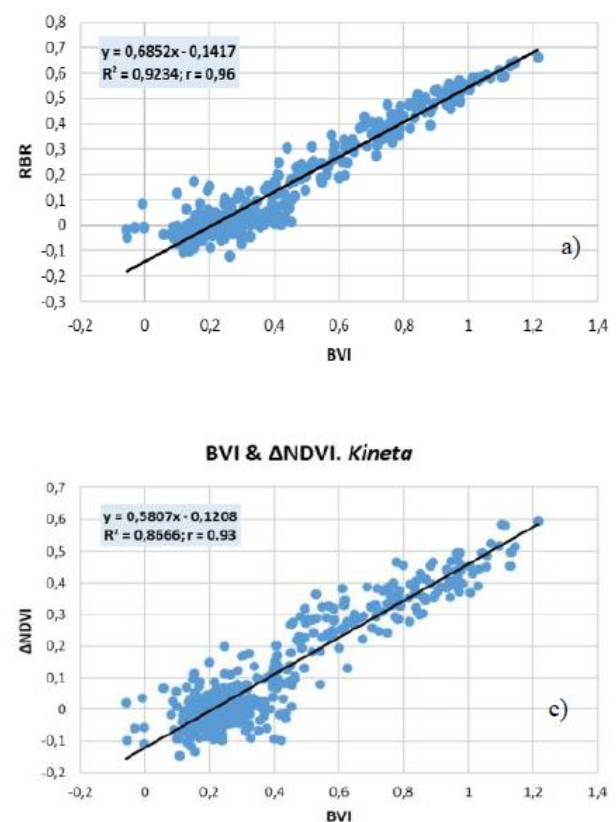

BVI \& $\triangle$ NBR. Kineta

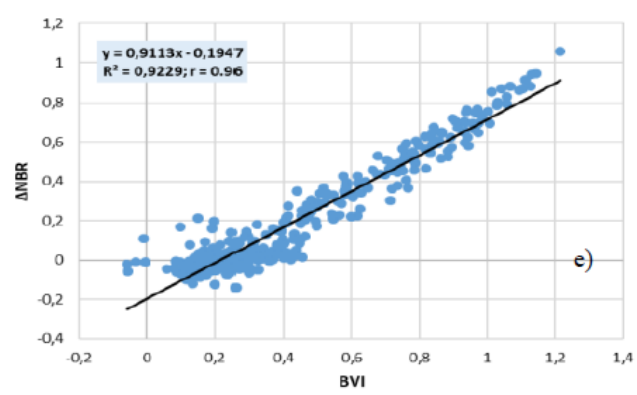

BVI \& RBR. Mati

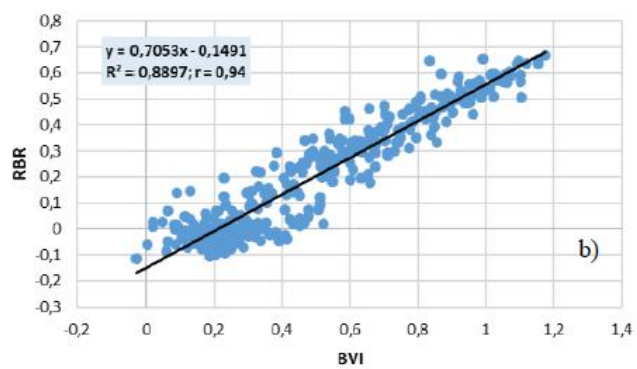

BVI \& $\Delta$ NDVI. Mati

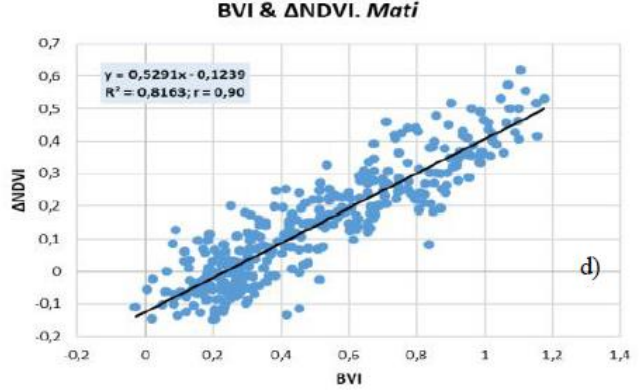

BVI \& ANBR. Mati

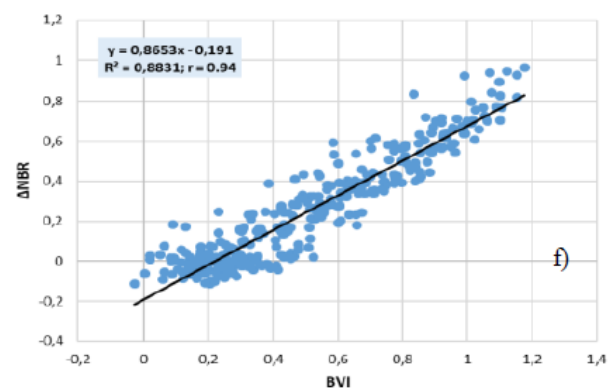

Fig. 11. Graphs correlating BVI and RBR, dNDVI, dNBR.

\section{R E F E R E N C E S}

Cantarello, E., Newton, A.C, Martin, P.A, Evans, P.M., Gosal, A., Lucash, M.S (2017) Quantifying resilience of multiple ecosystem services and biodiversity in a temperate forest landscape. Ecol. Evol, 7 (22), 9661-9675.

Chu, T., \& Guo, X. (2014) Remote Sensing Techniques in Monitoring Post-Fire Effects and Patterns of Forest Recovery in Boreal Forest Regions: A Review. Remote Sensing, 6 (1), 470-520.

Cigna, F., Del Ventisette, C., Liguori, V. \& Casagli, N. (2011) Advanced radar-interpretation of InSAR time series for mapping and characterization of geological processes. Natural Hazards and Earth System Sciences. 11 (3), 865-881. 
Cigna, F., Tapete, D. \& Casagli, N. (2012) Semi-automated extraction of Deviation Indexes (DI) from satellite Persistent Scatterers time series: tests on sedimentary volcanism and tectonicallyinduced motions. Nonlinear processes in geophysics, 19 (6), 643-655.

Copernicus EMS (2018) - Copernicus Emergency Management Service. EMSR300: Forest Fires in Attika, Greece. Available from: https://emergency.copernicus.eu/mapping/list-ofcomponents/EMSR300 [Accessed October 2019].

Copernicus Open Access Hub (2018) - Available from: https://scihub.copernicus.eu [Accessed October 2018].

Chuvieco, E. (1999). Remote Sensing of Large Wildfires in the European Mediterranean Basin, Springer, New York.

Díaz-Delgado, R. \& Pons, X. (1999) Empleo de imágenes de teledetección para el análisis de los niveles de severidad causados por el fuego. Revista de Teledetección, 12, 63-68.

Doblas-Miranda, E., Martínez-Vilalta, J., Lloret, F., Álvarez, A., Ávila, A., Bonet, F. J., Brotons, L., Castro, J., Curiel Yuste, J., Díaz, M., Ferrandis, P., García-Hurtado, E., Iriondo, J. M., Keenan, T. F., Latron, J., Llusià, J., Loepfe, L., Mayol, M., Moré, G., Moya, D., Peñuelas, J., Pons, X., Poyatos, R., Sardans, J., Sus, O., Vallejo, V. R., Vayreda, J. \& Retana, J. (2015) Reassessing global change research priorities in mediterranean terrestrial ecosystems: how far have we come and where do we go from here? Global Ecology and Biogeography, 24 (1), 25-43.

Du, Y., Zhang, Y., Ling, F., Wang, Q., Li, W., \& Li, X. (2016) Water Bodies' Mapping from Sentinel-2 Imagery with Modified Normalized Difference Water Index at 10-m Spatial Resolution Produced by Sharpening the SWIR Band. Remote Sens, 8 (4), 354.

Eidenshink, J., Schwind, B., Brewer, K., Zhu, Z.L., Quayle, B. \& Howard, S. (2007) A project for monitoring trends in burn severity. Fire Ecol, 3 (1), 3-21.

Escuin, S., Navarro, R. \& Fernández, P. (2008) Fire severity assessment by using NBR (Normalized Burn Ratio) and NDVI (Normalized Difference Vegetation Index) derived from LANDSAT TM/ETM images. International Journal Remote Sensing, 29 (4), 1053-1073.

Fontúrbel, M. T., Fernández, C. \& Vega, J. A. (2015) Cambios en la repelencia al agua del suelo en función de la severidad del fuego en el suelo. Flamma, 6 (3), 122-124.

Furtună, P., Holobâcă, I.H. (2013) Forest fires study using Remote sensing and meteorological indicators. Study case. Geographia Technica, 8 (2), 23-37.

González De Vega, S., de las Heras, J., Gómez-Sánchez, E. \& Moya, D. (2015) Response of plant communities in the short-term after fire: influence of fire severity and resilience. Flamma, 6 (3), 149-153.

González-De Vega, S., de las Heras, J. \& Moya, D. (2016) Resilience of Mediterranean terrestrial ecosystems and fire severity in semiarid areas: Responses of Aleppo pine forests in the short, mid and long term. Science of the Total Environment, 573, 1171-1177.

Hasnat, Md. Mehedi, Islam, Md. Rakibul, Hadiuzzaman, Md. (2018) Emergency Response During Disastrous Situation in Densely Populated Urban Areas: a GIS Based Approach. Geographia Technica, 13 (2), 74-88.

Hedo, J., Rubio, E., Dadi, T., López-Serrano, F. R., Alfaro-Sánchez, R., Moya, D. \& De las Heras, J. (2014) Is Remote Sensing a Good Method to Define Forest Fire Resilience? A Particular Case in the South-eastern of the Iberian Peninsula, In: Viegas, D.X. (Ed.) Advances in forest fire research, 556-563, Coimbra: Universidade de Coimbra.

Hellenic Statistical Authority (2011) - Available from: http://www.statistics.gr/en/2011-census-pophous [Accessed October 2019]

Hudak, A.T., Morgan, P., Bobbitt, M.J., Smith, A.M.S., Lewis, S.A., Lentile, L.B., Robichaud, P.R., Clark, J.S. \& McKinley, R.A. (2007) The relationship of multispectral satellite imagery to immediate fire effects. Fire Ecol., 3 (1), 64-90.

Husson, A. (1983) Télédétection des incendies de forêt en Corse entre 1973 et 1980. Méditerranée, 54 (4), Télédéctection III., 53-59. 
Israel, G.D (1992) Determining Sample Size. University of Florida Cooperative Extension Service, Institute of Food and Agriculture Sciences, EDIS, Florida. Available from: https://www.tarleton.edu/academicassessment/documents/Samplesize.pdf [Accessed October 2019].

Jiang, D., Huang, Y., Zhuang, D., Zhu, Y., Xu, X. \& Ren, H. (2012) A Simple Semi-Automatic Approach for Land Cover Classification from Multispectral Remote Sensing Imagery. PLoS ONE, 7 (9). Available from: https://doi.org/10.1371/journal.pone.0045889 [Accessed October 2019].

Keeley. J.E. (2009) Fire intensity, fire severity and burn severity: a brief review and suggested usage. International Journal of Wildland Fire, 18 (1), 116-126.

Key, C.H. \& Benson, N.C. (2006) Landscape Assessment (LA): Sampling and Analysis Methods. In: Lutes, D., Keane, R.E., Caratti, J.F., Key, C.H., Benson, N.C., Sutherland, S., Gangi, L. (Eds.) Firemon: Fire Effects Monitoring and Inventory System, Gen. Tech. Rep. RMRS-GTR-164-CD, Fort Collins, CO: U.S. Department of Agriculture, Forest Service, Rocky Mountain Research Station, LA-1-55.

Lee, J. \& Wong, D.W.S.(2001) Statistical Analysis with ArcView GIS, John Wiley and Sons, New York.

Lyons, M.B., Keith, D.A., Phinn, S.R., Mason \& T.J., Elith, J. (2018) A comparison of resampling methods for remote sensing classification and accuracy assessment. Remote Sensing of Environment, 208 (11), 145-153.

Main-Knorn, M., Pflug, B., Louis, J., Debaecker, V., Müller-Wilm, U. \& Gascon, F. (2017) 'Sen2Cor for Sentinel-2', Image and Signal Processing for Remote Sensing XXIII . Proc. SPIE 10427, 1042704, SPIE REMOTE SENSING. Warsaw, Poland, 11-14 September 2017. Bellingham, Washington: SPIE.

MAPAMA (2016) - Ministerio de Agricultura, Pesca, Alimentación y Medio Ambiente. Available from: https://www.mapa.gob.es/es/desarrollo-rural/estadisticas/Incendios_default.aspx [Accessed October 2019].

Mateescu, M. (2006) Burnt Area Statistics 3D GIS Tool for Post-Fire Assessment. Geographia Technica, 1 (2), 56-65.

Miller, J.D., Safford, H.D., Crimmins, M. \& Thode, A.E. (2009) Quantitative evidence for increasing forest fire severity in the Sierra Nevada and southern Cascade Mountains, California and Nevada, USA. Ecosystems, 12 (1), 16-32.

Miller, J.D. \& Thode, A.E. (2007) Quantifying burn severity in a heterogeneous landscape with a relative version of the delta Normalized Burn Ratio (dNBR). Remote Sens. Environ., 109 (1), 66-80.

Mousivand, A., Verhoef, W., Menenti, M. \& Gorte, B. (2015) Modeling Top of Atmosphere Radiance over Heterogeneous Non-Lambertian Rugged Terrain. Remote Sens., 7 (6), 8019-8044.

Moya, D., Alfaro-Sánchez, R., López-Serrano, F. R., Dadi, T., Hernández-Tecles E., Ferrandis, P. \& de las Heras, J. (2014) Post-fire management of mediterranean forests: carbon storage in regenerated areas in eastern Iberian Peninsula. Cuadernos de Investigación Geográfica, 40 (2), 371-386.

Moya, D., De las Heras, J., Lopez-Serrano, F. R., Condes, S., Alberdi, I. (2009) Structural patterns and biodiversity in burned and managed Aleppo pine stands. Plant Ecology, 200 (2), 217-228.

Nicoară, P.S., Haidu, I. (2014) A GIS based network analysis for the identification of shortest route access to emergency medical facilities. Geographia Technica, 9 (2), 60-67.

Parks, S. A., Dillon, G. K. \& Miller, C. (2014) A New Metric for Quantifying Burn Severity: The Relativized Burn Ratio. Remote Sens., 6 (3), 1827-1844.

Paula, S., Arianoutsou, M., Kazanis, D., Tavsanoglu, Ç., Lloret, F., Buhk, C., Ojeda, F., Luna, B., Moreno, J. M., Rodrigo, A., Espelta, J. M., Palacio, S., Fernández-Santos, B., Fernandes, P. M. 
\& Pausas, J. G. (2009) Fire-related traits for plant species of the Mediterranean Basin. Ecology, $90(5), 1420$.

Pausas, J. G. (1999) Mediterranean vegetation dynamics: modelling problems and functional types. Plant Ecology, 140 (1), 27-39.

Raspini, F., Bianchini, S., Ciampalini, A., Del Soldato, M., Solari, L., Novali, F., Del Conte, S., Rucci, A., Ferretti, A. \& Casagli, N. (2018) Continuous, semi-automatic monitoring of ground deformation using Sentinel-1 satellites. Available at: https://www.nature.com/articles/s41598018-25369-w.pdf [Accessed October 2019].

Regueira, N., Benito, E., Fontúrbel, M. T., Fernández, C., Jiménez, E. \& Vega, J. A. (2015) Efectos de quemas experimentales de diferente severidad en el carbono orgánico y en propiedades físicas del suelo. Flamma, 6 (3), 129-133.

Sánchez, J. M., Rubio, E., López-Serrano, F. R., Artigao, M. M., Caselles, V., Moya, D. \& Odi, M. M. (2009). Estudio a través de imágenes Landsat 5-TM del efecto de un incendio sobre el balance de energía en superficie en una zona de bosque mediterráneo. Revista de Teledetección, 32 (6), 72-85.

San-Miguel-Ayanz, J. \& Camia, A. (2009) Forest fires at a glance: facts, figures and trends in the EU. In: Birot, Y. (Ed.) Living with Wildfires: What Science Can Tell Us. A Contribution to the Sciencepolicy Dialogue. Joensuu, Finland: European Forest Institute, 11-18.

Sever, M. (2019) Wildfires affect water resources long after the smoke clears. Eos, 100. Available at: https://doi.org/10.1029/2019EO134717 [Accessed October 2019].

Spano, D., Camia, A., Bacciu, V., Masala, F., Duguy, B., Trigo, R., Sousa, P., Venäläinen, A., Mouillot, F., Curt, T., Moreno, J. M., Zavala, G., Urbieta, I. R., Koutsias, N. \& Xystrakis, F. (2014) Recent trends in forest fires in Mediterranean areas and associated changes in fire regimes, In: Moreno, J. M., Arianoutsou, M., González-Cabán, A., Mouillot, F., Oechel, W. C., Spano, D., Thonicke, K., Vallejo, V. R., Vélez, R. (Eds.), Forest Fires Under Climate, Social and Economic Changes in Europe, the Mediterranean and other Fire-affected Areas of the World: FUME: lesson learned and outlook, Adelaïde: Calyptra Pty, 6-7.

Tessler, N., Wittenberg, L., Provizor, E. \& Greenbaum, N. (2014) The influence of short interval recurrent forest fires on the abundance of Aleppo pine (Pinus halepensis Mill.) on Mount Carmel, Israel. Forest Ecology Management, 324, 109-116.

UN-SPIDER Knowledge Portal - United Nations Office for Outer Space Affairs. Available from: http://un-spider.org/advisory-support/recommended-practices/recommended-practice-burnseverity/in-detail/normalized-burn-ratio [Accessed October 2019].

Vallejo, V. R., Arianoutsou, M. \& Moreira, F. (2012) Fire ecology and post-fire Restoration approaches in southern European forest types. In: Moreira, F., Arianoutsou, M., Corona,P., De Las Heras, J. (Eds.) Post-fire Management and Restoration of Southern European Forests, 93119. Netherlands: Springer.

Vega, J. A., Fontúrbel, T., Fernández, C., Díaz-Raviña, M., Carballas, T., Martín, A., GonzálezPrieto, S., Merino, A. \& Benito, E. (2013) Acciones urgentes contra la erosión en áreas forestales quemadas. Guía para su planificación en Galicia. Santiago de Compostela: Centro de Investigación Forestal de Lourizán, Consellería do Medio Rural e do Mar, Xunta de Galícia, Instituto de Investigaciones Agrobiológicas de Galicia del CSIC (IIAGCSIC), Universidad de Santiago de Compostela, Universidad de Vigo, FUEGORED.

Vlassova, L., Pérez-Cabello, F., Mimbrero, M. R., Llovería, R. M. \& García-Martín, A. (2014) Analysis of the Relationship between Land Surface Temperature and Wildfire Severity in a Series of Landsat Images. Remote Sensing, 6 (7), 6136-6162.

Zhu, Z., Key, C.H., Ohlen, D., Benson, N.C. (2006) Evaluate Sensitivities of Burn-Severity Mapping Algorithms for Different Ecosystems and Fire Histories in the United States. Available at: https://www.firescience.gov/projects/01-1-4-12/project/01-1-4-12_final_report.pdf [Accessed October 2019]. 